\title{
South African Coal Mining Industry: Socio-Economic Attributes
}

\author{
Ken Mathu \\ Vaal University of Technology \\ Richard Chinomona
}

Vaal University of Technology

\section{Doi:10.5901/mjss.2013.v4n14p347}

\begin{abstract}
Coal has been an important commodity in South Africa for many years and it is one of the oldest mining enterprises in the country. Its role since 1923 as a primary source of energy has steered the economy and society to prosperity. The energy generated especially electricity and synthetic fuels impacts on all sectors of the economy and the society. The country has enough coal for domestic consumption and for export to last the country for longer than it has existed. There are 73 collieries distributed through the coal mining areas with majority of them (61) situated in the Mpumalanga coalfields. The only problem with coal mining is raising carbon footprint and carbon emissions that have become a global issue for nearly the last two decades. The five leading coal mining companies (Anglo Coal, BHP Billiton, Exxaro, Xstrata and Sasol) produce over $80 \%$ of the South African coal. The rest is produced by junior miners that comprise the newly established Black Economic Empowerment companies. The domestic coal consumption is 75 percent of the total coal produced in the country while 25 percent is exported. The interactions of the role players in the coal mining industry commencing with the government regulations, supply chain members, employees and the society who are the beneficiaries of the process underpins the socioeconomic attributes of the industry.
\end{abstract}

Keywords: coal mining, electricity generation, socio-economic, supply-chain, synthetic-fuels

\section{Introduction}

The discovery of coal in South Africa over 100 years ago has significantly transformed the socio-economic landscape of the country. The process commenced with mining coal for space heating and cooking until 1923 when it replaced hydropower as a primary source of energy. The commodity has since expedited the industrial and agricultural development that continues to improve the life of the people despite the carbon emissions into the universe. This socioeconomic attribute is beneficial at all levels of the society.

The use of coal as a primary source of energy, for fuel and petrochemical production underpins its importance in the national wealth creation. It contributes significantly to the gross domestic product (GDP). The people working in its supply chain and the economic impacts of its utility signify its socio-economic attributes to the country.

The coal supply chain benefits various organisations owning the transportation modes ranging from the State owned company Transnet that owns and runs the railway system, third-party logistics (3PL) companies for road transport and the coal terminals (sea ports) for coal export. However, the bulk of South African coal is transported to the coal-fired power stations via conveyor belts as most of the existing power stations were strategically located next to the coal mines for the ease of transportation costs.

Over 80 percent of South African coal is produced by five leading international natural resources companies namely BHP Billiton, Anglo Coal, Xstrata, Exxaro and Sasol. The rest of the coal is produced by smaller black empowerment companies which are also affiliated to the main role players in the industry. The coal produced is 75 percent for domestic market and 25 percent for export market. Approximately, the total coal produced is consumed by Eskom power stations for the generation of electricity.

A significant amount of coal is transformed into liquid fuels (Coal-to-Liquid) and some of it processed into petrochemical products by Sasol. Eskom is the leading emitter of carbon-dioxide followed by Sasol, making South Africa one of the global top 20 worst countries in carbon emissions.

The socio-economic attributes of coal mining industry in South Africa can be chronicled from domestic to industrial applications. The social impacts range from home to institutional energy use. The other aspect comprises energy 
demand and supply for sustainable development to fulfill developmental agenda.

\section{Problem Statement}

The problem statement for the study is to establish the socio-economic attributes of coal mining industry supply chain in South Africa and show need for improved collaboration and integration by the role players in both public and private sectors. The industry impacts from the days of coal discovery to present times are explored and articulated.

\section{The Purpose of the Study}

The purpose of this study was to establish how coal mining and its supply chain impacts on the socio-economic aspects of South Africa. The study was carried out by looking at the coal usage from the time of its discovery to present times, critically looking at factors that include:

1. Generation of electricity

2. Transformation into liquid fuels and petrochemical products

3. Raw use at home and industry

4. Role players in the coal supply chain

The outcome of the study aims to show the importance of coal mining industry, its socio-economic development attributes to the country and the need to streamline collaboration and integration of coal supply chain by all the role players.

\section{Methodology}

This study has adopted a qualitative research paradigm. According to Cooper and Schindler (2008: 162-168) the outcome of the qualitative interview depends very much on how the researcher prepares the participants for the interview. 'Qualitative research has substance, gives insight, shows sensitivity and is unique in conceptualisation, yet grounded in data' (Corbin \& Strauss 2008: 302).

This study covers various aspects that include selection of participants, undertaking the interview, feedback on the interview for validity/reliability and facilitating data collection in a recorded form using an audio data recorder and field notes. Citing Goddard and Melville (2005: 49) the researcher must not direct the participant's answer through his tone of voice or rephrase the research question. Research design involves activities of 'collecting and analysing data, developing and modifying theory, elaborating or refocusing the research questions, identifying and addressing validity threat' (Maxwell 2005: 2).

A purposive sampling process was used for the selection and profile of participants. The process aimed to enhance understanding of the selected people or groups as they were selected for a specific purpose, task or expertise in research. 'The researcher should be in a position to expound the use of purposive sampling in order to instill confidence and validity for research findings' (Devers \& Frankel 2000: 264-265). The participants for this study were the top professionals who were also involved in decision making in their organisations in order to provide credibility to the study. There were 14 respondents earmarked for this research and 13 of them responded: 12 respondents were interviewed at their work place while 1 respondent provided a telephonic interview. The interview population of the 13 respondents comprised 4 Chief Executives and 9 senior professionals in the mining and affiliated industries nominated by their respective chief executives.

\subsection{Sample and procedures}

In order to obtain access to individuals and institution, the researcher is required to obtain permission from gate-keepers of the target institutions (Ehigie \& Ehigie 2005: 622-623). The permission to conduct research either oral or written is paramount (Cooper \& Schindler 2008: 37). The objectives for the research were addressed at the initiation stage as the researcher approached the institutions' gate-keepers by stipulating the value proposition for the study, purpose and ethical considerations that also addressed the 'informed consent' (admissibility for research process).

The researcher requires skills in negotiation and relationship building to be able to successfully access the prospective respondents. In this study, the researcher approached the selected participants via telephone and e-mail and briefed them on the value proposition for the project. Since the respondents were senior executives in their respective 
companies, some of them responded directly, while the others responded through their personal assistants. In two occasions the researcher was invited to give a presentation on the purpose of the research before the consent to interview was granted. A research introduction letter from the Vaal University of Technology formed part of the presentation. The content of the letter included the introduction of the researcher, confidentiality undertakings and the use of audio digital data recorder for recording the interviews.

\subsection{Data analysis}

The research data was collected from the respondents using the audio digital data recorder and from the field notes. The collected data was transcribed and content analysis was used for the translation and analysis. The emerging themes and sub-themes were recorded and evaluated establishing the socio-economic attributes of the industry in South Africa.

\subsection{Reliability and validity (Measures of Trustworthiness)}

The reliability and validity of data from this study were ascertained through triangulation: comparing data from the interviews, feedback from the participants and from the literature. The researcher's field notes articulated the respondents' output. Some participants also provided written clarifications of some of their contributions after the interview. 'Multiple sources lead to a better understanding of the phenomena being studied' (Willis 2007: 219). Triangulation enhances validity and richness of data by looking at issues from different angles (Lee \& Lings 2008: 239).

\subsection{Ethical procedures}

According to Eriksson and Kovalainen (2008: 68) research is vulnerable to 'lies, fraud and wrong-doing' hence, ethical adherence is paramount. The ethical issues for this study were addressed through the research introduction letter from the Vaal University of Technology addressed to those participants who had accepted the invitation for the interview. The letter provided confidentiality, anonymity and use of pseudonyms between the respondent and the researcher.

\section{Results}

The findings revealed the socio-economic attributes of coal mining industry and role players to the society and the country. Four major themes emerged out of the study that included coal as a commodity, legislative environment, industry role players and the environmental issues. Emanating from the broad categories that were identified were several sub-themes and they are expressed in Table 1.

Table 1: Themes and Sub-Themes Emanating from the Interviews

\begin{tabular}{|c|c|}
\hline Themes & Sub-Themes \\
\hline $\begin{array}{l}\text { Coal: origin, reserves, quality, business model, } \\
\text { production, consumption and trade (economic } \\
\text { benefits/welfare of employees and communities }\end{array}$ & $\begin{array}{ll}\text { - } & \text { Coal and its properties, reserves, production, consumption and trade } \\
\text { - } & \text { Employee satisfaction } \\
- & \text { Community welfare } \\
- & \text { Environmental impacts } \\
\end{array}$ \\
\hline 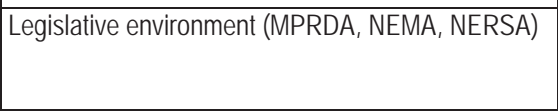 & $\begin{array}{ll}- & \text { MPRDA Act of } 2002 \\
- & \text { NEMA Act of } 1998 \\
- & \text { NERSA }\end{array}$ \\
\hline $\begin{array}{l}\text { Role players: coal mines (private), Transnet - rail } \\
\text { infrastructure (public) and South African Chamber } \\
\text { of Mines (private) }\end{array}$ & $\begin{array}{ll}- & \text { Coal mines } \\
\text { - } & \text { Transnet (rail transport) } \\
- & \text { South African Chamber of Mines (advisory role to the mining industry) }\end{array}$ \\
\hline $\begin{array}{l}\text { Environmental issues: pursuing green management } \\
\text { issues as per legislations, funders and social } \\
\text { responsibility. Committed to "cradle to grave" } \\
\text { philosophy of green environment }\end{array}$ & 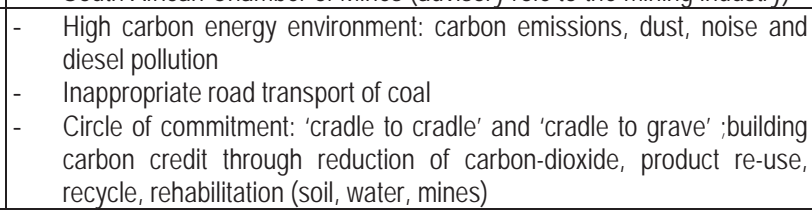 \\
\hline
\end{tabular}

Source: Mathu (2011: 222-223) 


\section{Discussion}

A number of factors indicating the socio-economic attributes of the South African coal mining industry supply chain emerged from the interviews conducted with professionals who are also involved in decision making in the industry and the role players as elaborated herewith.

\subsection{The socio-economic attributes of coal mining in South Africa}

According to the respondents the coal mining impacts on the society and the general economy of the country are observed from the early days of pick and shovel coal mining to present highly mechanised mining process. The coal use for space heating and cooking from the early days to the present cannot be overemphasised as the poor communities in villages, townships and informal settlements continue to use it. Over 70 percent of communities in South Africa have access to electricity emanating from thermal coal. As a primary energy source, coal impacts on national development plans for industry, institutions and infrastructures among others. South Africa is one of the leading producers of coal in the world and has reserves that could last more than 100 years under the present rate of consumption. The socioeconomic impacts of coal mining is realised far beyond the coal supply chain. The attributes were expressed by critically examining various aspects and roles of the coal supply chain and role players including what coal is as a commodity, reserves, a South African business model, coal production, consumption and trade.

\subsection{Coal and its properties}

Coal is a fossil fuel and a primary source of energy in South Africa. Coal is formed from accumulation of dead vegetation over many years, undergoing a slow decaying process turning into peat that transforms into coal seams (Anglo Coal 2007: 47). According to Abbott, Apostolic, Goodman, Hortsman, Jenner, Jewell, Labhart, Maragos, May, Sunderman, Parke, Stein, Wengler and Went (2009: 53) the slow formation process that takes millions of years make coal a nonrenewable source of energy.

South African coal is associated with the Karoo rock formations which extend over the present day Free State, Mpumalanga, Limpopo and Western Natal. The chemical composition and properties of coal determine its usage. South African coal is less reactive, harder and has lower sulphur content compared to coal from the Northern hemisphere. The bulk of South African coal is bituminous or thermal grade suitable as fuel for electricity generation and anthracite suitable for metallurgical plants (Lang 1995: 20).

Carbon contents determine the calorific value (heat value) and it is used in the classification of coal (Abbott et al., 2009: 53) viz:

- Lignite coal: It is the lowest ranked coal with carbon content of $25-35 \%$ and it is mainly used in power stations to generate electricity.

- Sub-bituminous coal: It has higher calorific value than lignite, contains $35-45 \%$ carbon and its main use is also as fodder for the power stations.

- Bituminous coal: It has higher calorific value than sub-bituminous, contains $45-86 \%$ carbon and it is used for power generation and in the metallurgy industry as 'coke' for the production of iron and steel.

- Anthracite coal: It is the highest ranked coal in quality and it is hard, glossy and black. It possesses the highest calorific value, contains $86-97 \%$ carbon and it is mainly used for residential and commercial space heating.

- Graphite coal: It possesses the same quality with anthracite and it is mainly used in pencil making and as a lubricant when powdered.

\subsection{South African coal reserves}

South Africa has coal reserves of approximately 30408 million tons, the sixth largest coal reserves in the world. The coal reserves are found in Mpumalanga, Free State, Limpopo, Kwa-Zulu Natal and Limpopo coalfields (DMR 2009:44).

The South African coalfields are mainly concentrated in the Mpumalanga coalfields where most of the coal-fired power plants are situated. The 650 kilometres rail line that transports coal to the Richards Bay Coal Terminal for export also runs from this area. Mpumalanga Province presently produces in excess of 70 percent of the South African coal, but the reserves are currently running low (depleting). It is estimated that from around 2020, coal mines in the Mpumalanga 
area will start relocating to the Waterberg coalfields in Limpopo Province which has abundant, untapped coal reserves (Chamber of Mines 2009:27).

The following map shows the distribution of the South African coalfields.

Map 1: South African Coalfields, 2008

\section{South African Coalfields}

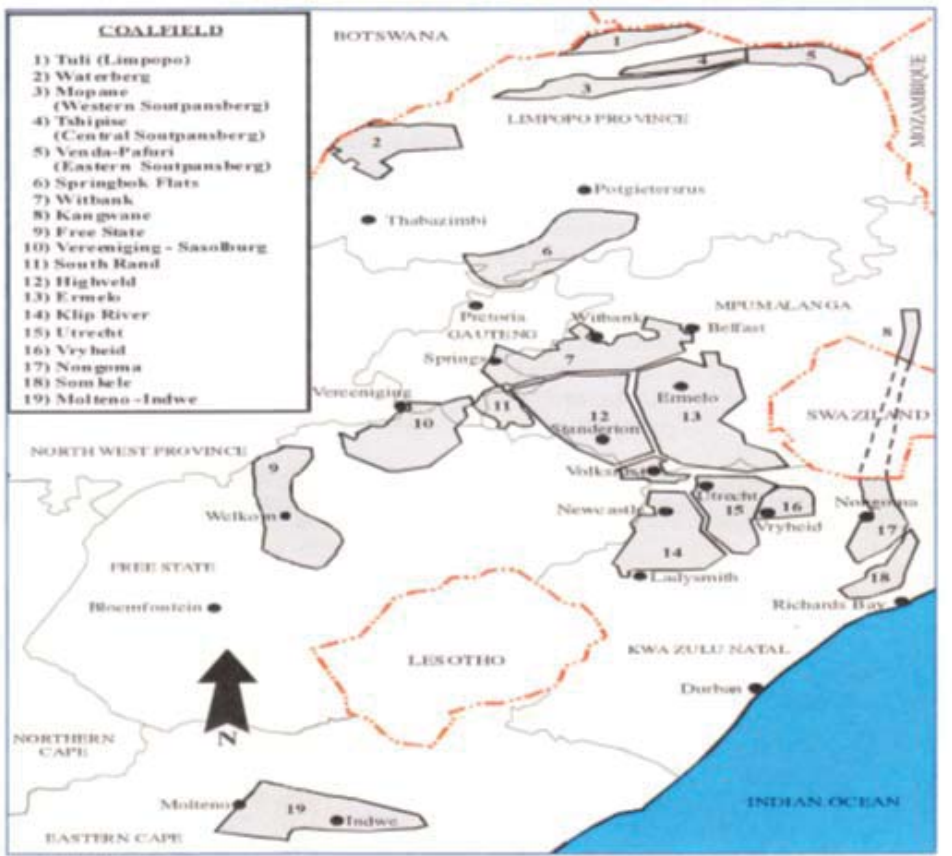

\section{Source: Prevost 2008:6}

Map 1 show that most of the South African coal reserves are concentrated in the areas of Witbank, Ermelo, Highveld in Mpumalanga, and Waterberg in Limpopo.

There were 73 collieries in South Africa based on a 2007 survey. A number of them are owned by the five leading mining companies that produce over 80 percent of coal in the country and the others are owned by smaller mining companies called 'junior miners' and that includes the newly established Black Economic Empowerment mining companies. The national distribution of the collieries are: Free State (2); Gauteng (1); Kwazulu-Natal (7), Limpopo (2) and Mpumalanga (61). The five leading mining companies involved in the exploitation of coal from these coalfields are Anglo Coal, BHP Billiton, Exxaro, Xstrata and Sasol (DME 2007:44).

\subsection{South African coal mining business model}

The South African coal mining business model for domestic consumption is based on three stages. The stages comprise the mining process, transportation to the domestic customers/consumers and the processes at the customers' facilities who are usually the consumers. The export coal is transported by rail to the main coal export terminal at Richards Bay along the Indian ocean coast of Kwa-Zulu Natal and shipped to the markets abroad.

The following figure shows the South African coal mining business model. 
Figure 1: The South African Coal Mining Business Model

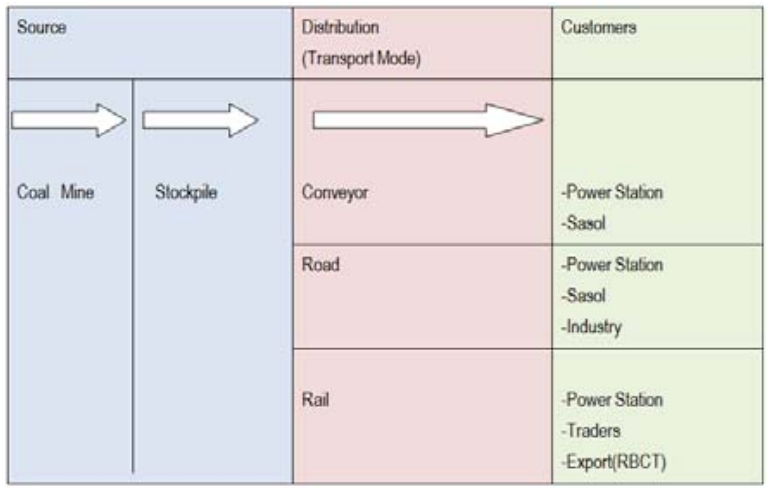

Source: Mathu 2011: 63

The South African coal mining business model has three main stages: source (coal mining/ beneficiation), transportation mode (type of transport used) and customers/ consumers.

\subsubsection{Stage 1: Mining}

The mining process involves removal of overburden on the top of the mine and coal that is brought to the surface mixed with rocks. The rocks are sorted from coal and delivered to a dump site. Coal free of rocks is stockpiled on a site allocated near the mine.

\subsubsection{Stage 2: Distribution (Transportation)}

Three types of transport modes are used for local distribution to the customers (conveyor, rail and road) while rail and ship are used for export. The power station coal is delivered direct from the stockpiles and does not go through the beneficiation process. The bulk of the power station coal is delivered via conveyor belts. The rest is delivered by road and rail. The export coal is taken through the beneficiation process and delivered to the export terminal by rail. The coking coal for metallurgical industry, coal for other industries and for traders is delivered by road and rail.

\subsubsection{Stage 3: Customers}

The domestic customers for coal are the power stations, SASOL, industry and traders while the export customers abroad are the power stations and industry.

\section{Coal Production}

South African coal production has stagnated since 2004 while consumption by Eskom has risen to meet the continued rising power demand. The scenario puts Eskom in competition with the other domestic consumers, resulting in price hikes and this has forced Eskom to use discarded coal from the big coal exporters in order to meet their requirements. The demand will continue to outstrip supply for some time until new coal mines come on stream (Smuts 2008:36).

Over 80 percent of saleable coal production in South Africa is supplied by mines controlled by the largest five mining groups: Anglo Coal, BHP Billiton, Exxaro, Sasol and Xstrata. The rest is produced by the junior miners that include the Black Economic Empowerment (BEE) in partnership with other established miners. Approximately 75 percent of coal mined in South Africa is used locally, mainly for electricity generation (Eskom power stations) and Sasol's transformation into liquid fuels/petrochemicals (Eskom, PED 2008:1). 


\section{Coal Consumption}

The coal consumption in South Africa comprises domestic consumption and export. The domestic consumption is predominantly by Eskom power stations for the generation of electricity, Sasol for transformation into synthetic fuels and petrochemical products and industry/homes for various applications.

\subsection{Coal for the generation of electricity (Eskom)}

Eskom is a South African government-owned power utility company that consumes the bulk of coal produced in the country as fuel for the generation of electricity through its current 13 coal-fired power plants which generate 88 per cent of the national electricity (Eskom 2009: 226). Eskom is one of the top 10 utilities in the world by generation capacity (Eskom 2009: iii). This is an indication of the size and capacity of the utility. The company's electricity generation mix comprises coal, hydro, pumped storage and some imports. This brings the total nominal capacity to 44193 megawatts (MW) (Eskom 2009: iii).

Eskom consumes approximately 50 percent of the coal produced in South Africa and approximately 66 percent of the total domestic coal consumption. Its consumption in 2011 was 124.7 million tons of coal (Eskom 2011: 11). The power crisis of 2007/2008 impacted heavily on the company and on the economy as well as communities. The coal stockpile at the power stations had deteriorated due to poor coal logistics, among other factors. As a result, Eskom was forced to step up coal transport by road to the detriment of the environment in the Mpumalanga area where most of the coal-fired stations are located (Bischoff 2009: 100).

This study established during the interviews that coal transportation is done 70 percent by conveyor belts, 24 percent by road and 6 percent by rail. The future plan is to reduce road transport to below 6 percent and increase rail transport to more than 24 percent. Eskom is under pressure to control costs and rail transport is viewed as being more economical, safer and sustainable.

Eskom uses a network of national grid to transmit and distribute power directly or through municipalities. The national grid comprises 395 419km power lines (Eskom 2011: 169).

\subsection{Coal for production of liquid fuels and petrochemical products (Sasol)}

South African Synthetic Oils (Sasol) is a South African public company founded in 1950 and is listed on both the Johannesburg stock exchange (JSE) and New York Stock Exchange (NYSE). The company supplies a third of South Africa's liquid fuel requirements. It is also the country's single largest industrial investor, as well as the largest chemical feedstock producer. Its contribution to the Growth Domestic Product (GDP) is 4.7 percent amounting to R 40 billion a year (Sasol 2008:69-70).

'Sasol's primary business is based on CTL and GTL technology using Fischer-Tropsch synthesis. CTL and GTL plants convert coal and natural gas respectively into liquid fuels. The company has GTL projects countries such as Qatar, Nigeria and china. However, the only problem with the use of the Fischer-Tropsch synthesis is the massive emission of carbon dioxide into the atmosphere. Indeed, the company's Secunda plant is one of the world's single largest emitter of carbon dioxide.' (Sasol 2008: 83).

\subsection{Coal use in industry and homes}

Coal is transformed under high temperature of approximately 1000 degrees Celsius into coke for use as a reducing agent fuel in the smelters in blast furnaces (Crawford 1993: 5). It is used for cooking and space heating in homes and industries (Chamber of mines 2009: 25).

\section{Coal Trade}

The South African coal trade falls under two categories namely domestic and export markets. The domestic market is dominated by Eskom and Sasol which including local industry and domestic market comprises 75 percent of total coal produced in the country. The remaining 25 percent is exported. In 2008, the South African coal market was estimated to be 252.2 Million tons (Mt) comprising 194.3 Mt for the domestic market and $57.9 \mathrm{Mt}$ for export. Based on these numbers the coal produced distribution ratios are as follows: power generation - Eskom (124.35mtpa), Sasol (44mtpa), industries 
(9mtpa), merchants (12.25mtpa) and exports (57.9mtpa) (Prevost 2008:7).

The following table indicates the South Africa's production and sale of coal for a ten year period, 1999-2008.

Table 2: South Africa's Production and Sale of Coal, 1999-2008

\begin{tabular}{|c|c|c|c|c|c|c|c|}
\hline \multicolumn{2}{|c|}{} & \multicolumn{3}{|c|}{ Local Sales } & \multicolumn{3}{c|}{ Export Sales } \\
\hline Year & Production & Mass & \multicolumn{2}{|c|}{ Free On Rail (FOR) } & Mass & \multicolumn{2}{c|}{ Free On Board (FOB) } \\
\hline & Million ton (Mt) & Mt & R'000 & R/t & Mt & R'000 & R/t \\
\hline 1999 & 222,3 & 154,6 & 8305568 & 53 & 66,2 & 9234328 & 142 \\
\hline 2000 & 224,1 & 154,6 & 8772310 & 57 & 69,9 & 11185460 & 160 \\
\hline 2001 & 223,5 & 152,2 & 9564521 & 63 & 69,2 & 16956659 & 245 \\
\hline 2002 & 220,2 & 157,6 & 11773123 & 75 & 69,2 & 19366998 & 280 \\
\hline 2003 & 239,3 & 168,0 & 13212837 & 79 & 71,5 & 13490623 & 189 \\
\hline 2004 & 242,8 & 178,3 & 13606151 & 76 & 67,9 & 14472904 & 213 \\
\hline 2005 & 245,0 & 173,4 & 14878140 & 86 & 71,4 & 21155176 & 296 \\
\hline 2006 & 244,8 & 177,0 & 16245861 & 92 & 68,7 & 21745322 & 316 \\
\hline 2007 & 247,7 & 182,8 & 19718642 & 108 & 67,7 & 24447656 & 361 \\
\hline 2008 & 252,2 & 197,1 & 30119929 & 153 & 57,9 & 42447656 & 732 \\
\hline
\end{tabular}

\section{Source: DMR 2009: 46}

Table 2 shows the coal trade in South Africa for a ten year period, 1999-2008. It includes coal production in the ten years, for domestic and export markets with their respective prices. The production appears almost constant as there were very little variations between the years. For instance, in 1999 production was $222.3 \mathrm{Mt}$ and in 2008 it was $252.2 \mathrm{Mt}$. There is little variation in the local prices, but export prices indicate a huge variation in the two years, 2007 (R 361/t) and 2008 (R 732/t).

The local coal price per ton Free on Rail (FOR) averaged R 150.40 per ton in 2008 , a 40.5 percent increase on the 2007 price. The average export price FOB (Free on Board) was R 704.62 per ton in 2008, a 94.5 increase over the 2007 price. The rise in local price was mainly attributed to higher mining costs resulting from higher input costs. The price of coal used in the domestic electricity sector increased by 25.7 percent averaging at R 111.82 per ton in 2008 and for the first three months of 2009 , the price rose by 10.6 percent to $\mathrm{R} 123.66$ per ton FOR.

\section{Legislative Environment}

\subsection{Department of Mineral Resources (DMR)}

The Department of Mineral Resources (DMR), previously Department of Minerals and Energy (DME), uses the Mineral and Petroleum Resources Development Act (MPRDA) - Act 2002 (Act No. 28 of 2002) that was promulgated in April 2004 in the administration of the mining industry (Government Gazette 2010: 3).

\subsection{Department of Water and Environmental Affairs (DW\&EA)}

The Department of water and environmental affairs (DW \& EA) ensures that mines has environmental management plan (EMP) based on the principle of integrated environmental management as provided by the National Environmental Management Act (Act No. 107 of 1998) NEMA (Government Gazette 2010: 3).

\subsection{National Energy Regulator of South Africa (NERSA)}

The National Energy Regulator of South Africa (NERSA) is the precursor National Energy Regulator (NER) established in October 2005 to regulate the energy sectors in electricity, piped gas and petroleum. It is the role of regulating electricity that is of concern in this research as it relates to the fuel used (coal) in the generation of electricity (NERSA 2009: 5).

Established under Section 3 of the National Energy Regulator Act, 2004 (Act No. 4 of 2004), NERSA's mandate is to maintain a delicate balance between the regulated energy industries, users and consumers (NERSA 2008:16). The regulatory body advises the electricity and other energy institutions on the tariffs they charge the consumers and 
arbitrates grievances between the consumers and the energy distributors, among other roles. This ensures that the end users and consumers receive appropriate service and pay the correct rates recommended by the government (NERSA 2009:11-15).

\section{The Key Role Players in the South African Coal-Mining Industry Supply Chain}

The key role players in the South African coal-mining industry supply chain comprise mining companies, government departments responsible for minerals and environmental affairs, domestic and export coal customers, rail logistics company Transnet, the main coal export terminal at Richards Bay and the Chamber of Mines of South Africa.

\subsection{South African coal mines}

The two methods of mining used in South Africa are opencast and underground methods. Opencast mining (surface mining) is applicable when the coal seam is close enough to the earth's surface. The process involves removing the earth (overburden) which covers the coal seam and then blasting the seam to remove the coal. The equipment used includes draglines, shovels, front-end-loaders, bucket-wheel excavators and trucks. The overburden removed is kept separately then returned back to the mine after coal has been extracted (Lloyd 2002:1-4).

A report from Eskom indicates that mining development has stalled in the last four years. It also indicates a projection of up to 2018 comprising 43 new mines at an estimated cost of about R 100 billion and raising the 2008 national production estimate of $270 \mathrm{mtpa}$ to $370 \mathrm{mtpa}$ by 2018 . Those mines would be developed by the existing leading mining groups in the industry and just a few to be developed by the Black Economic Empowerment companies (Eskom 2009: 15).

\subsection{Transnet (rail transport)}

'Transnet is a South African government-owned corporation which is the operator and custodian of South Africa's major transport infrastructure (rail, harbours and pipelines). The entity ensures that the country's freight transportation system operates according to world-class standards and as an integral part of the overall economy.' (Transnet 2009:2).

'Transnet is featured as one of the most important logistics companies in the coal industry. The railway service is predominantly used to transport export coal to the Richards Bay Coal Terminal, a distance of 650 kilometres from Mpumalanga coalfields. It also transports some coal to the Eskom power plants.' (Transnet 2008:136).

Its business unit, Transnet Freight Rail (TFR), is responsible for rail freight. The main focus of TFR is transporting bulk and containerised freight. During the 2007/2008 period, the division transported 179.9 million tons of freight for export and domestic customers, (Transnet 2008:10). This figure went down during 2008/2009 to approximately 177 million tons (Transnet 2009: 2).

\subsection{Richards Bay Coal Terminal (RBCT)}

The port of Richards Bay is situated 170 kilometres north of Durban on the Indian ocean coastline. It was opened in 1976 and commenced with an export capacity of 10Mtpa. This capacity grew over the years and reached a capacity of 72Mtpa in 2008 (Goussard 2009:8). The capacity reached 76mtpa in 2009 (Prevost 2009: 7) and by 2010 its expansion reached $91 \mathrm{mtpa}$. Richards Bay Coal Terminal (RBCT) is the largest single coal export terminal in the world, exporting more than 69 million tons annually (DMR 2009:47). In 2011 the port exported 65.5mt (Mining Weekly 2012: 1).

\subsection{Chamber of Mines of South Africa}

The Chamber of Mines of South Africa is a voluntary membership private organisation which was founded in 1889 to look into the affairs of the mining industry. The Chamber liaises with universities and international organisations for mining related research and bridges between the government, labour unions and the mining industry (Chamber of Mines 2009: i). 


\subsection{The future of coal mining in South Africa}

The future of South African coal mining lies in coalfields which were identified in the past, but were never exploited due to constraints such as the lack of infrastructure, difficult coal mining conditions, high ash content and low calorific value (CV). 'These massive areas include Waterberg, Springbok Flats, Limpopo, Soutpansberg, Tuli, Mabopane, Venda-Pafuri and the Free State coalfields. They contain younger coal compared to that of Mpumalanga coalfields. The Waterberg coalfields alone contain about 3.4 billion tons of coal or 11 percent of South African recoverable coal.' (Prevost 2008: 6-9)

The South African coal mining sector has medium and long-term plans to increase coal production capacity. 'Presently, the industry has R15.5 billion worth of projects underway which could yield about $36 \mathrm{Mt}$ of extra coal production, while also sustaining production at some mines. Another $63 \mathrm{Mt}$ worth about $\mathrm{R} 30$ billion is in the final feasibility stage. It is estimated that about R100 billion will be invested in the industry over the next decade if targets are to be achieved.' (Chamber of Mines 2009:27).

With the Mpumalanga coalfields being presently overexploited, the future of South African coal production lies in the Waterberg coal fields in the Limpopo Province (Prevost 2010:17). Eskom plans to construct new power stations in the area in future, commencing with the R110 billion Medupi dry-cooled coal power station which is under construction outside Lephalale. The feedstock for the giant power plant of about 14.6 million tons of coal per year will be supplied by the Grootegeluk coal mine owned by Exxaro Resources. Another new power station with the same capacity Kusile is also under construction near the area and it will be supplied coal by Anglo Coal.

The availability of water is a significant factor in the coal-mining industry. Large volumes of water are needed for mining, beneficiation and processing purposes (Prevost 2008:11). 'In the case of the Waterberg coalfield, the availability of water is a major inhibiting factor. 'The Matimba power station uses water from Makola Dam outside Lephalale. Presently, more water could become available by raising the level of Makola Dam, but it would not be enough for the earmarked development in the area. A geo-hydrology study is also being carried out to establish the availability of water in the area.' (Van Vuuren 2009:15).

The mining Act MPRDA of 2002 introduced transformation in the South African mining industry as a whole through the Broad-based socio-economic empowerment charter for the South African mining industry. In the coal mining industry, Black Economic Empowerment coal mining companies have grown from 2 in 2002 to 29 in 2008 making a very important contribution to the coal export market (DMR 2009:47).

Most of these BEE coal mining companies are small, but others have established partnerships with large, existing companies. For instance, Exxaro emerged from the merger, in 2006, of former Kumba Resources (Anglo American) and Eyesizwe Coal (black company) to form the biggest empowerment coal-mining company (Exxaro 2007:3).

\section{Limitation of the Study}

The study being qualitative had a limitation on the number of participants. A total of 13 professionals from the coal mining industry and the role players were interviewed. Recruiting such high caliber professionals was time-consuming in accessing them and their institutions as explained in the methodology chapter. However, the response by the respondents from the industry was positive (13 approvals out of 14 proposals).

Accessing the industry had other limitations due to its nature as energy industry and energy is a sensitive subject because of its critical role in sustainable development. The institutions in the industry are not easily accessible without convincing reasons and introducing a research topic is not one of the most desired reasons to gain access. However, with skills and patience, it was possible to gain access and to successfully accomplish the project.

\section{Recommendations}

Recommendations for this study are classified under general and policy issues as follows:

\subsection{General recommendations:}

- The coal mining industry needs to move from internal focus to cross-enterprise collaborations. Such collaborations would enable industry players to look beyond the profit focus and start seeing the value of cooperation and information sharing with the other members of the value chain.

- An Integrated strategy on the development of the coal mining industry (ISDCM) need to be developed to 
facilitate communication among the role players in the coal mining industry.

- The industry should have long-term plans for skills development to address the skills deficiencies in the industry at all times.

- There should be a shift from road to rail for coal transportation to limit the environmental degradation by trucks.

\subsection{Policy recommendations}

At a policy level the study recommends that the coal mining industry develops an Integrated Strategy on the Development of Coal Mining (ISDCM) for South Africa. The critical elements of the strategy should be:

- a policy legislative environment;

- working towards a common and shared vision in the industry;

- developing rail and infrastructure;

- developing skills;

- attracting new investors in the industry;

- diversifying ownership of the rail and Transnet; and

- managing the environment.

\section{References}

Abbott, K., Apostolik, R., Goodman, G., Jenner, M., Labhart, G., Maragos, S., May, M., Sunderman, A. D., Parke, J., Stein, J., Wengler, J. \& Went, P. 2009. Foundation of Energy Risk Management: An overview of the energy sector and its physical and financial markets. Global Association of Risk Professional (GARP). Hobken, NJ: John Wiley.

Anglo Coal. 2007. Annual Report.

Bischoff, F. 2009. Coal haulage. IMIESA, October, pp.100-101.

Chamber of Mines of South Africa. 2009. Annual Report.

Cooper, D. R. \& Schindler, P. S. 2008. 10th ed. Business Research Methods. New York: McGraw-Hill.

Corbin, J. \& Strauss, A. 2008. $3^{\text {rd }}$ ed. Basics of Qualitative Research. Thousand Oaks (CA): Sage.

Crawford, O. 1993. Surface molecular anchoring in microfined liquid crystals near the nematic-smectic-A transition. [Online]. Available at: http://link.aps.org/doi/10.1103/PhysRevE.48.1998. Accessed. 23 April 2009.

Denvers, K.J. \& Frankel, M. 2000. The study design in qualitative research-2: Sampling and Data Collection Strategies. Education for Health, Vol. 13, No. 2, pp. 263-271.

Ehigie, B. O. Ehigie, R. I. 2005. Applying qualitative methods in organisations: A note for industrial/organizational psychologists. The Qualitative Report Volume 10 Number 3 September, pp. 621-638. [Online.] Available at: http://www.nova.edu/ssss/QR/QR103/ehigie.pdf. Accessed: 13 September 2010.

Eskom, Primary Energy Division. 2008. Annual Report.

Eskom. 2009. Annual Report.

Eskom. 2011. Annual Report.

Exxaro. 2007. Annual Report.

Goddard, W. \& Melville, S. 2005. 2nd ed. Research Methodology (An Introduction). Durban: Juta.

Kovalainen, A. 2008. Qualitative Methods in Business Research. London: Sage.

Lang, J. 1995. Coal Mining In the Life of South Africa. Cape Town: Jonathan Ball.

Lee, N. \& Lings, I. 2008. Doing Business Research: A Guide to Theory and Practice. London: Sage.

Lloyd, P. J. 2002. Coal Mining and Environment. Energy Research Institute, University Of Cape Town.

Mathu, K. M. 2011. Supply Chain Constraints in South African Coal Mining Industry. Berlin: Lap Lambert.

Mining Weekly. 2012. [Online]. Available at: www.miningweekly.com Accessed: 10 January 2012.

Maxwell, J. A. (2005). $2^{\text {nd }}$.Ed. Qualitative Research Design: An Alternative Approach. Thousand Oaks (Ca): Sage.

National Energy Regulator of South Africa (Nersa). (2008). Annual Report.

National Energy Regulator of South Africa (Nersa). (2009). Annual Report.

Prevost, X. (2008). Coal Mining In South Africa. Inside Mining, Pp. 6-9.

Prevost, X. (2010). A Clean Future for Coal. Inside Mining, April/May, Pp. 14-17.

Republic Of South Africa (Rsa). Department Of Minerals and Energy. 2007/2008. South Africa's Mineral Industry (Sami). Pretoria: Government Printers.

Republic Of South Africa (Rsa). Department Of Mineral Resources. (2009). Molato (Bana Le Basadi Ba Tlile Go Tlo Rera Molato). Johannesburg: Primedia.

Republic Of South Africa (Rsa). Department Of Mineral Resources. (2010). Mining Licenses Moratorium No. 33511, Vol. 542, Pretoria, 31 August. 
Sasol. (2008). Sustainable Development Result.

Smuts, W. (2008). Why Coal Is King. Inside Mining, September, Pp33-37.

Transnet. (2008). Annual Report.

Transnet. (2009). Annual Report.

Van Vuuren, L. (2009). Coal Mining's Impact on Waterberg under Microscope. The Waterwheel Journal, March/April, P. 14.

Willis, J. W. (2007). Foundations of Qualitative Research (Interpretive and Critical Approach). London: Sage. 